\title{
RENAL EXCRETION OF INORGANIC PHOSPHATE IN NEWBORN INFANTS ${ }^{1,2}$
}

\author{
By WALLACE W. MCCRORY, 3 CAROLYN W. FORMAN,4 HELEN MCNAMARA, AND \\ HENRY L. BARNETT
}

\author{
(From the New York Hospital and the Department of Pediatrics, Cornell University Medical \\ College, New York City)
}

(Submitted for publication August 17, 1950; accepted January 28, 1952)

\section{INTRODUCTION}

Because of the important role phosphate plays in many body functions and since phosphate absorbed in excess of body needs is excreted mainly by the kidneys, detailed studies of renal excretion of phosphate have been made in dogs and in adult human subjects, especially by Pitts and his coworkers (1-3). Mechanisms involved in renal excretion of phosphate in young infants are of interest for additional reasons. The serum phosphate concentration is higher in young infants than in adults and especially so in infants receiving cow's milk of high phosphorus content (4). This high serum phosphate concentration in young infants has been attributed to a limitation in renal excretion of phosphate (4-7) and has been implicated as a factor of importance in hypocalcemic tetany of the newborn $(8,9)$. In addition, it has been suggested that "the paucity of phosphates in infant urines must be a great handicap to them in excreting acids and may explain many of the accepted facts about their susceptibility to an acidosis" (10). A limitation in renal excretion of phosphate in young infants is implied as underlying these physiologic consequences. However, the renal mechanisms responsible for such a limitation, if indeed it exists, have not been described. The present investigations were undertaken to examine more completely the renal excretion of phosphate in young infants.

1 This investigation was supported in part by research grants from the National Institutes of Health, Public Health Service, and Playtex Park Research Institute.

2 Presented in part before the Society for Pediatric Research, French Lick, Indiana, May 8, 1950.

3 Lewis Cass Ledyard, Jr. Fellow in Pediatrics, 1949 50. Present address : Children's Hospital of Philadelphia, Philadelphia, $\mathrm{Pa}$.

4 Public Health Service Postdoctorate Research Fellow, 1949-51.

\section{SUBJECTS AND METHODS}

Twenty-two series of observations were made on a total of 19 subjects including two normal adults, one premature infant and 16 full-term newborn infants. The clinical diagnosis of neonatal tetany had been made in seven of the infants (TR, AC, EU, EN, MI, GU, and $\mathrm{BH})$ because of hypocalcemia and increased neuromuscular irritability with or without convulsions. In these infants observations were performed prior to the institution of specific therapy. The remaining nine infants were normal newborn infants.

All infants received cow's milk formulas of similar caloric, calcium, and phosphorus content. In addition each received 14,000 units of Vitamin $A, 2,500$ units of Vitamin D, and $50 \mathrm{mg}$. of ascorbic acid daily after the sixth neonatal day. Observations were made in the morning at least three hours after feedings, and subjects were fasted throughout experimental periods. Blood specimens were drawn from scalp and peripheral veins into syringes coated with mineral oil. Hemolysis was negligible. Standard technics were used for determination of calcium in serum (11) and phosphorus in serum and urine (12).

With one exception (FL) in which only endogenous creatinine clearances were done, glomerular filtration rate (GFR) was measured in all observations on infants by the clearance of inulin, using the catheterization technic previously described (13). In 11 observations, inulin was given by continuous infusion and in seven by single injection. In observations on the two normal adults, urines were obtained by spontaneous voidings.

To determine excretion of phosphate unaffected by experimental procedures (i.e., inulin infusion, parathormone injection, etc.) GFR was estimated by the endogenous creatinine clearance corrected by the creatinine: inulin clearance ratio, measured later in the same observation in all but one instance (FL). The creatinine: inulin clearance ratio is derived from the average value for each of these functions measured simultaneously during the experimental procedure. The validity of this method of estimating GFR in the absence of infusions is attested to by $C_{C R}: C_{I N}$ mean ratio for the total observations of 1.03 (Table II).

\section{PROCEDURES}

The concentration in serum and rate of urinary excretion of inorganic phosphate was measured simultaneously with estimations of GFR under the following conditions: 
1) At endogenous serum inorganic phosphate concentration in nine infants and in the two adults. The serum phosphate concentration was below the accepted upper limit of normal, $2.5 \mathrm{mM} / \mathrm{L}$., in five infants, all of whom were normal; it was above this value in four of the infants, three of whom had neonatal tetany, and one of whom was normal.

2) In six normal newborn infants ( $V A, M C, G O, R I$, $H O, R Y)$ whose serum phosphate concentration was elevated by a single oral dose of phosphate ( 0.5 to $1.5 \mathrm{gm}$. $\mathrm{Na}_{2} \mathrm{HPO}_{4} / \mathrm{Kg}$.) administered in water by gavage. The larger dose regularly produced frequent loose stools. Serum phosphate was elevated to levels of $4.0-4.7 \mathrm{mM} / \mathrm{L}$. in one to two hours. The change in serum phosphate during individual collection periods (15-20 minutes) did not exceed $0.7 \mathrm{mM} / \mathrm{L}$. and was $0.3 \mathrm{mM}$ or less in most periods. Hypocalcemia of varying degrees developed in association with the induced hyperphosphatemia. Though serum calcium fell to as low as $1.6 \mathrm{mM} / \mathrm{L}$. (6.4 mg./100 ml.) no infants developed clinical signs of tetany.

Similar observations with single feedings of phosphate were made in one normal infant (RY), before and after a period of ingestion of aluminum hydroxide gel (daily dosage of $6.4 \mathrm{ml} . / \mathrm{Kg}$.) for five days.

3) Before and after intravenous injection of parathyroid extract in three normal infants ( $S H, G O$, and $F L$ ) and in four infants with neonatal tetany (TR, $A C, E N$, $E U)$.

\section{RESULTS}

\section{A. Observations on renal phosphate excretion in relation to endogenous serum phosphate con- centration}

Values for serum phosphate concentrations and rates of filtration, reabsorption and excretion of phosphate together with the creatinine: inulin clearance ratios and corrected creatinine clearances in nine infants who had no preceding treatment which might affect these functions are presented in Table I.

The results show rather wide variations in individual values for rates of filtration, reabsorption, and excretion of phosphate in the nine infants. Differences in rates of excretion (and reabsorption) of phosphate were not related, however, to differences in endogenous serum phosphate concentration. In the five infants whose serum phosphate concentrations were $2.5 \mathrm{mM} / \mathrm{L}$. or less, mean values for rates of phosphate filtered, reabsorbed, and excreted were $17.9,15.4$, and 2.5 micromols/ min. compared with values of 17.4, 15.1, and 2.3 in the four infants with higher concentrations of serum phosphate. If the rate of phosphate excretion is expressed as the fraction of filtered phosphate excreted, a similar range and mean value is found in the two groups. Thus, though the two groups differ in their serum phosphate concentrations they show no related differences in filtered phosphate load or its disposition. Since filtered phosphate is the product of serum phosphate concentration and glomerular filtration rate, the fact that the groups fail to show differences in filtered phosphate implies that glomerular filtration rate is lower on the average in those infants with higher serum phosphate concentrations.

TABLE I

Renal excretion of inorganic phosphate in relation to endogenous serum phosphate concentrations in newborn infants

$C_{C R} / C_{I N}$ represents the ratio of mean values for $C_{C R}$ and $C_{I N}$ for all periods (3-11) in each observation during which simultaneous measurements were made. Corrected $C_{C R}$ is the mean $C_{C R}$ of the pre-infusion periods (1-3) corrected by this ratio. Values given for phosphate also represent mean values for the pre-infusion periods.

\begin{tabular}{|c|c|c|c|c|c|c|c|c|}
\hline \multirow{2}{*}{ Subject } & \multirow{2}{*}{$\underset{\text { status }}{\text { Clinical }}$} & \multirow{2}{*}{$\underset{\mathbf{P}}{\text { Serum }}$} & \multirow{2}{*}{$\mathrm{C}_{\mathrm{CR}} / \mathrm{C}_{\mathrm{IN}}$} & \multirow{2}{*}{$\underset{\text { Corrected }}{\text { Cor }}$} & \multicolumn{3}{|c|}{ Phosphate (micromols/min.) } & \multirow{2}{*}{$\mathrm{C}_{\mathbf{P}} / \mathrm{C}_{\mathrm{IV}}$} \\
\hline & & & & & Filtered & Reabsorbed & Excreted & \\
\hline \multirow[t]{2}{*}{$\begin{array}{l}\text { FL } \\
\text { SH } \\
\text { GO } \\
\text { RI } \\
\text { GD }\end{array}$} & $\begin{array}{l}\text { Normal } \\
\text { Normal } \\
\text { Normal } \\
\text { Normal } \\
\text { Normal }\end{array}$ & $\begin{array}{c}m M / L . \\
2.2 \\
2.3 \\
2.3 \\
2.4 \\
2.5\end{array}$ & $\begin{array}{l}0.95 \\
1.05 \\
1.06 \\
1.00\end{array}$ & $\begin{array}{c}\text { ml. } / \text { min } \\
6.3^{*} \\
7.8 \\
9.1 \\
8.6 \\
6.5\end{array}$ & $\begin{array}{l}13.9 \\
17.9 \\
20.9 \\
20.6 \\
16.3\end{array}$ & $\begin{array}{l}12.1 \\
15.6 \\
18.8 \\
16.5 \\
14.0\end{array}$ & $\begin{array}{l}1.8 \\
2.3 \\
2.1 \\
4.1 \\
2.3\end{array}$ & $\begin{array}{l}.13 \\
.13 \\
.10 \\
.20 \\
.14\end{array}$ \\
\hline & Mean & 2.3 & 1.02 & 7.7 & 17.9 & 15.4 & 2.5 & .14 \\
\hline \multirow[t]{2}{*}{$\begin{array}{l}\text { AC } \\
\text { BO } \\
\text { EU } \\
\text { EN }\end{array}$} & $\begin{array}{l}\text { Tetany } \\
\text { Normal } \\
\text { Tetany } \\
\text { Tetany }\end{array}$ & $\begin{array}{l}2.7 \\
2.8 \\
2.9 \\
2.9\end{array}$ & $\begin{array}{l}0.88 \\
1.02 \\
0.90 \\
1.00\end{array}$ & $\begin{array}{l}6.7 \\
6.9 \\
6.2 \\
4.9\end{array}$ & $\begin{array}{l}18.1 \\
19.3 \\
18.0 \\
14.2\end{array}$ & $\begin{array}{l}15.9 \\
17.1 \\
15.4 \\
12.0\end{array}$ & $\begin{array}{l}2.2 \\
2.2 \\
2.6 \\
2.2\end{array}$ & $\begin{array}{l}.12 \\
.11 \\
.14 \\
.15\end{array}$ \\
\hline & Mean & 2.8 & 0.95 & 6.2 & 17.4 & 15.1 & 2.3 & .13 \\
\hline
\end{tabular}

* In this single instance in which no inulin clearance was done, the endogenous creatinine clearance was corrected by the mean creatinine:inulin ratio (1.03) determined in observations on the other infants (see Table II). 
TABLE II

Relation of endogenous serum phosphate concentrations to glomerular filtration rate in newborn infants

\begin{tabular}{|c|c|c|c|c|c|c|c|c|c|}
\hline Subject & $\begin{array}{c}\text { Clinical } \\
\text { data }\end{array}$ & Sex & Age & Weight & S. A. & $\underset{P}{\text { Serum }}$ & $\mathrm{C}_{\mathrm{IN}}$ & $\mathrm{C}_{\mathrm{CR}}$ & $\mathrm{C}_{\mathrm{IN}} / \mathrm{C}_{\mathbf{C R}}$ \\
\hline $\begin{array}{l}\text { VA } \\
\text { MC } \\
\text { SH } \\
\text { GO } \\
\text { RI } \\
\text { GD }\end{array}$ & $\begin{array}{l}\text { Normal } \\
\text { Normal } \\
\text { Normal } \\
\text { Normal } \\
\text { Normal } \\
\text { Normal }\end{array}$ & $\begin{array}{l}\mathbf{M} \\
\mathbf{M} \\
\mathbf{M} \\
\mathbf{M} \\
\mathbf{M} \\
\mathbf{F}\end{array}$ & $\begin{array}{l}\text { days } \\
10 \\
14 \\
10 \\
11 \\
14 \\
6\end{array}$ & $\begin{array}{l}K_{g} . \\
3.46 \\
4.10 \\
3.25 \\
3.60 \\
3.78 \\
3.30\end{array}$ & $\begin{array}{l}M^{2} \\
.23 \\
.27 \\
.22 \\
.24 \\
.25 \\
.23\end{array}$ & $\begin{array}{c}m M / L . \\
2.1 \\
2.3 \\
2.3 \\
2.3 \\
2.4 \\
2.5\end{array}$ & $\begin{array}{c}\text { ml./min. } \\
6.3 \\
8.4 \\
8.5 \\
8.6 \\
7.1 \\
6.5\end{array}$ & $\begin{array}{c}\text { ml./min. } \\
6.7 \\
9.3 \\
8.1 \\
9.0 \\
7.5 \\
6.5\end{array}$ & $\begin{array}{l}1.06 \\
1.11 \\
0.95 \\
1.05 \\
1.06 \\
1.00\end{array}$ \\
\hline Mean & & & 10.8 & 3.60 & 0.24 & 2.3 & 7.6 & 7.9 & 1.04 \\
\hline $\begin{array}{l}\text { TR } \\
\text { AC } \\
\text { BO } \\
\text { EU } \\
\text { EN } \\
\text { MI } \\
\text { GU } \\
\text { BH }\end{array}$ & $\begin{array}{l}\text { Tetany } \\
\text { Tetany } \\
\text { Normal } \\
\text { Tetany } \\
\text { Tetany } \\
\text { Tetany } \\
\text { Tetany } \\
\text { Tetany }\end{array}$ & $\begin{array}{l}\mathbf{F} \\
\mathbf{M} \\
\mathbf{F} \\
\mathbf{M} \\
\mathbf{M} \\
\mathbf{F} \\
\mathbf{M} \\
\mathbf{F}\end{array}$ & $\begin{array}{r}8 \\
7 \\
16 \\
12 \\
5 \\
19 \\
14 \\
8\end{array}$ & $\begin{array}{l}3.00 \\
3.37 \\
4.48 \\
3.83 \\
3.20 \\
4.20 \\
3.72 \\
3.20\end{array}$ & $\begin{array}{l}.21 \\
.23 \\
.29 \\
.25 \\
.22 \\
.27 \\
.25 \\
.22\end{array}$ & $\begin{array}{l}2.7 \\
2.7 \\
2.8 \\
2.9 \\
2.9 \\
3.0 \\
3.0 \\
3.1\end{array}$ & $\begin{array}{l}4.2 \\
6.7 \\
6.5 \\
7.0 \\
5.2 \\
6.5 \\
7.5 \\
4.9\end{array}$ & $\begin{array}{l}3.7 \\
5.9 \\
6.6 \\
6.3 \\
5.2 \\
7.8 \\
8.3 \\
5.7\end{array}$ & $\begin{array}{l}0.88 \\
0.88 \\
1.02 \\
0.90 \\
1.00 \\
1.20 \\
1.11 \\
1.16\end{array}$ \\
\hline Mean & & & 11.1 & 3.63 & 0.24 & 2.9 & 6.1 & 6.2 & 1.02 \\
\hline
\end{tabular}

The values for glomerular filtration rates and endogenous serum phosphate concentrations in 14 of the infants are presented in Table II, together with pertinent clinical data. Inulin clearances for six infants, whose endogenous serum phosphate concentrations were known but whose control rates of phosphate excretion were not measured, are included in this table.

The mean value for inulin clearances in the six infants whose serum phosphate concentrations were $2.5 \mathrm{mM} / \mathrm{L}$. or less was $7.6 \mathrm{ml} . / \mathrm{min}$. compared with a value of 6.1 in eight infants with serum phosphate concentrations above $2.5 \mathrm{mM} / \mathrm{L}$.
The two groups have the same mean value for surface area, $0.24 \mathrm{M}^{2}$; hence the difference in rate of glomerular filtration is not a reflection of differences in surface area.

\section{B. Effect of induced acute elevation of serum phos- phate on renal mechanisms of phosphate excretion}

Since we failed to observe a relationship between the rate of tubular reabsorption of phosphate and endogenous serum phosphate concentration in these infants, the study of the maximal or limiting

TABLE III

Effect of rapid elevation of serum phosphate concentration on renal excretion of phosphate in an infant

\begin{tabular}{|c|c|c|c|c|c|c|c|c|c|c|}
\hline \multirow{2}{*}{ Subject } & \multirow{2}{*}{ Period } & \multirow{2}{*}{$\begin{array}{l}\text { Elapsed } \\
\text { time }\end{array}$} & \multirow{2}{*}{$\underset{\mathbf{P}}{\text { Serum }}$} & \multirow{2}{*}{$\mathrm{C}_{\mathbf{I N}}$} & \multirow{2}{*}{$\mathrm{C}_{\mathrm{CR}}$} & \multicolumn{3}{|c|}{ P (micromols/min.) } & \multirow{2}{*}{$\mathbf{C}_{\mathbf{P}}$} & \multirow{2}{*}{$C_{P} / C_{n N}$} \\
\hline & & & & & & Filtered & Reabsorbed & Excreted & & \\
\hline \multirow{4}{*}{$\begin{array}{c}\text { RI } \\
2 \text { weeks } \\
\text { 3.78 Kg. }\end{array}$} & $\begin{array}{l}1 \\
2\end{array}$ & $\begin{array}{c}\min . \\
0-30 \\
31-58\end{array}$ & $\begin{array}{c}m M / L \\
2.5 \\
2.4\end{array}$ & $\begin{array}{l}\text { ml./mix. } \\
8.3^{*} \\
8.8^{*}\end{array}$ & \multirow[t]{2}{*}{$\begin{array}{c}\text { ml./min. } \\
8.8 \\
9.3\end{array}$} & \multirow[t]{2}{*}{$\begin{array}{l}20.8 \\
21.1\end{array}$} & \multirow[t]{2}{*}{$\begin{array}{l}16.6 \\
17.1\end{array}$} & \multirow[t]{2}{*}{$\begin{array}{l}4.2 \\
4.0\end{array}$} & \multirow[t]{2}{*}{$\begin{array}{c}m l . / m i n . \\
1.68 \\
1.67\end{array}$} & \multirow[t]{2}{*}{$\begin{array}{l}.20 \\
.19\end{array}$} \\
\hline & \multirow{3}{*}{$\begin{array}{l}3 \\
4 \\
5 \\
6 \\
7\end{array}$} & \multicolumn{3}{|c|}{$\begin{array}{l}\text { Single injection of inulin at } \\
65 \mathrm{~min} \text {. } \\
1.8 \mathrm{gm} . \mathrm{Na}_{2} \mathrm{HPO}_{4} \text { at } 72 \mathrm{~min} \text {. }\end{array}$} & & & & & & \\
\hline & & \multirow{2}{*}{$\begin{array}{l}121-143 \\
144-163 \\
164-185 \\
186-205 \\
206-225\end{array}$} & $\begin{array}{l}3.5 \\
4.1\end{array}$ & $\begin{array}{l}7.3 \\
7.1\end{array}$ & $\begin{array}{l}7.7 \\
7.6\end{array}$ & $\begin{array}{l}25.6 \\
29.1\end{array}$ & $\begin{array}{l}14.3 \\
13.7\end{array}$ & $\begin{array}{l}11.3 \\
15.4\end{array}$ & $\begin{array}{l}3.23 \\
3.76\end{array}$ & $\begin{array}{l}.44 \\
.53\end{array}$ \\
\hline & & & $\begin{array}{l}4.4 \\
4.2\end{array}$ & $\begin{array}{l}6.8 \\
7.5\end{array}$ & $\begin{array}{l}7.6 \\
7.2\end{array}$ & $\begin{array}{l}29.9 \\
31.5\end{array}$ & $\begin{array}{l}12.4 \\
13.9\end{array}$ & $\begin{array}{l}17.5 \\
17.6\end{array}$ & $\begin{array}{l}3.98 \\
4.19\end{array}$ & $\begin{array}{l}.59 \\
.56\end{array}$ \\
\hline
\end{tabular}

* Values calculated from endogenous creatinine clearance corrected on the basis of subsequently determined creatinine:inulin clearance ratio. 
rate of tubular reabsorption of phosphate was attempted.

Pitts and Alexander (1) demonstrated a relatively stable limiting rate of phosphate reabsorption in dogs when sufficient inorganic phosphate was infused to increase rate of filtration of phosphate well above the maximal rate of tubular reabsorption of phosphate. Assuming that differences in maximal or limiting rates of phosphate reabsorption (as distinguished from rate of reabsorption at endogenous serum phosphate concentrations) could exist in these infants, observations on infants were made before, during, and after rapid elevation of serum phosphate.

The protocol of a typical observation (RI) is shown in Table III. The calculated rate of reabsorption did not change significantly though a marked increase in rate of filtration of phosphate occurred with elevation of serum phosphate. The increase in rate of filtration of phosphate was consequently associated with an equivalent increase in phosphate excretion. The significant finding was the absence of an increase in rate of tubular reab- sorption of phosphate as serum phosphate was elevated. The pattern of response in six normal infants (VA, MC, GO, RI, HO, RY) is shown graphically in Figure 1. All values were corrected to $1.73 \mathrm{M}^{2}$ for comparison. The linear relationship between increasing rates of filtration and excretion of phosphate defines a limited rate for phosphate reabsorption. The finding of a limited or maximal rate for phosphate reabsorption in these infants is in agreement with the observations of Pitts and Alexander (1) and Harrison and Harrison (14) in adult human subjects and dogs. The maximal rate for phosphate reabsorption at elevated serum phosphate concentrations in these infants receiving cow's milk of high phosphate content did not differ significantly from the rate of reabsorption at their endogenous concentrations of serum phosphate. Since the rate of phosphate reabsorption is apparently independent of rapid increases in serum phosphate, the endogenous value for tubular reabsorption under these circumstances is identical with the physiologic maximal or limiting rate of phosphate reabsorption.

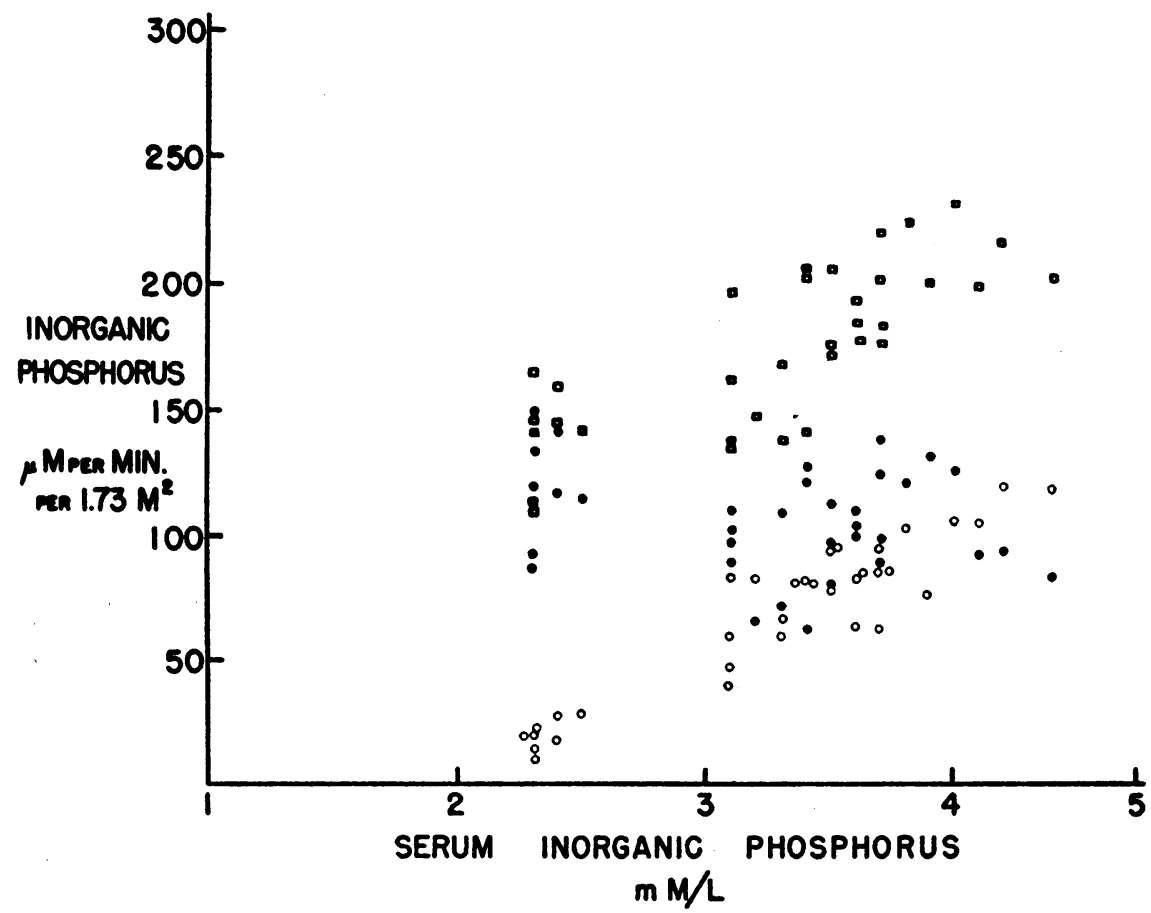

Fig. 1. Effect of Rapid Elevation of Serum Phosphate Concentration on Renal Excretion of Phosphate in Six Infants

Symbols designate values for rates of filtration (open squares), reabsorption (dots) and excretion (open circles) of phosphate. 


\section{Effect of reduced intestinal absorption of phos- phate on renal excretion of inorganic phos- phate}

The administration of aluminum hydroxide gel has been shown to reduce markedly the amount of dietary phosphorus available for intestinal absorption and to decrease urinary excretion of phosphate $(15,16)$. Accordingly this drug induces a state which may be considered comparable to that obtaining with low dietary intake of phosphate. Advantage was taken of this effect to examine the accompanying changes in renal excretion of inorganic phosphate in one normal infant (RY). Values for serum phosphate, glomerular filtration rate and renal excretion of phosphate observed in subject RY before and after he had received aluminum hydroxide gel for five days are given in Table IV. In addition after control periods in each observation, serum phosphate was elevated by phosphate ingestion. Although serum phosphate, glomerular filtration rate and consequently filtered phosphate are quite comparable in the two observations, a striking difference is observed in phosphate reabsorbed and excreted. In the second observation at endogenous serum phosphate concentrations, almost no phosphate was being excreted into the urine, which in the presence of an unchanged rate of filtration of phosphate represents a marked increase in rate of tubular reabsorption of phosphate. At both endogenous and elevated concentrations of serum phosphate the rate of tubular reabsorption is markedly increased following aluminum hydroxide gel. This change in rate of tubular reabsorption has reduced by over 50 per cent the rate at which a large load of phosphate is excreted.

These data indicate that reduction in dietary phosphorus is accompanied by decreased phosphate excretion due to increased tubular reabsorption of phosphate with no change in serum phosphate concentration. ${ }^{5}$ Furthermore, it appears that the limiting rate of phosphate reabsorption which

S It should be pointed out that these changes in reabsorption have been demonstrated to be independent only of the fasting endogenous serum phosphate concentration. It is possible that reduction in dietary intake might influence diurnal variations in serum phosphate (16), which in turn might be concerned in the factors regulating reabsorption.

TABLE IV

Renal excretion of phosphate at endogenous and rapidly elevated serum phosphate concentrations before $(A)$ and after $(\vec{B})$ administration of aluminum hydroxide gel

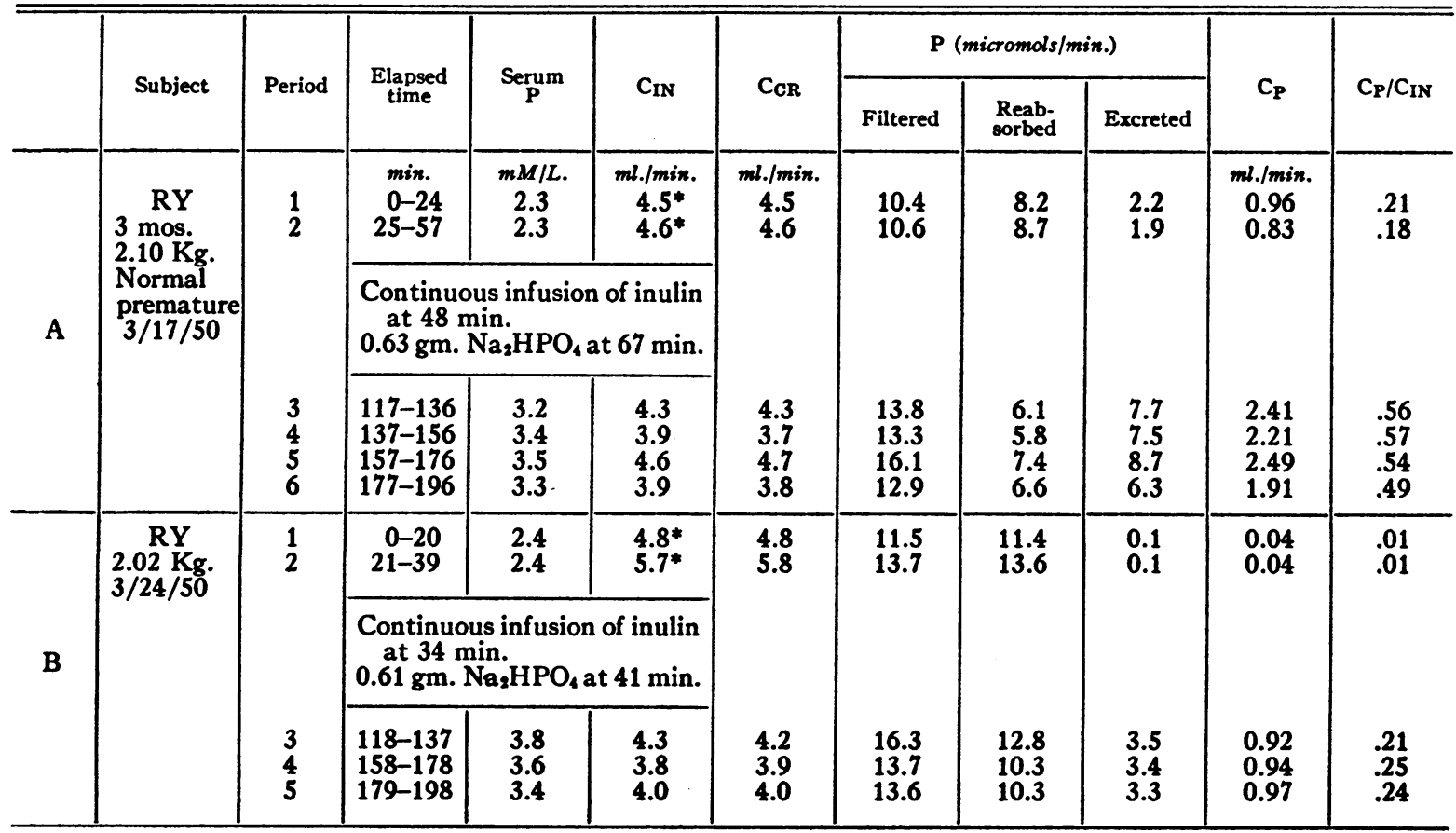

* Values calculated as explained in Table III. 
is demonstrable under given conditions is a physiologic reflection of homeostatic adjustments and is not a specific tubular function independent of hormonal and metabolic influence.

\section{Effect of parathyroid extract on renal excre- tion of phosphate}

The effect of parathyroid extract on serum phosphate concentration, glomerular filtration rate and renal excretion of phosphate was consistent in all observations made on each of seven infants $(\mathrm{SH}$, GO, FL, TR, AC, EU, EN). The protocol of a typical response is given in Table V (EU). Data from an infant (GU) not given parathyroid extract but treated similarly in every other respect are included in Table $\mathrm{V}$ as a control observation. A significant increase in phosphate excretion regularly followed the intravenous injection of 15 units of parathyroid extract. In a single observation
(FL), no response followed 10 units of parathyroid extract given intravenously. The magnitude of the response was independent of the endogenous serum phosphate concentration. As can be seen from Table. $V$, the observed increases in phosphate excretion could not be accounted for by increases in glomerular filtration rate or serum phosphate concentration but could be attributed only to significant decreases in rate of phosphate reabsorption. The changes observed in phosphate reabsorption and excretion following parathyroid extract exceeded spontaneous or diurnal changes or experimental variations as can be judged from the control observation presented.

These observations support the findings of Harrison and Harrison (14) and Michie and Shorey (17) that one effect of parathyroid extract administered intravenously is to increase renal excretion of phosphate by decreasing the rate

TABLE V

A. Effect of intravenous injection of parathyroid extract on renal excretion of phosphate

B. Control observation

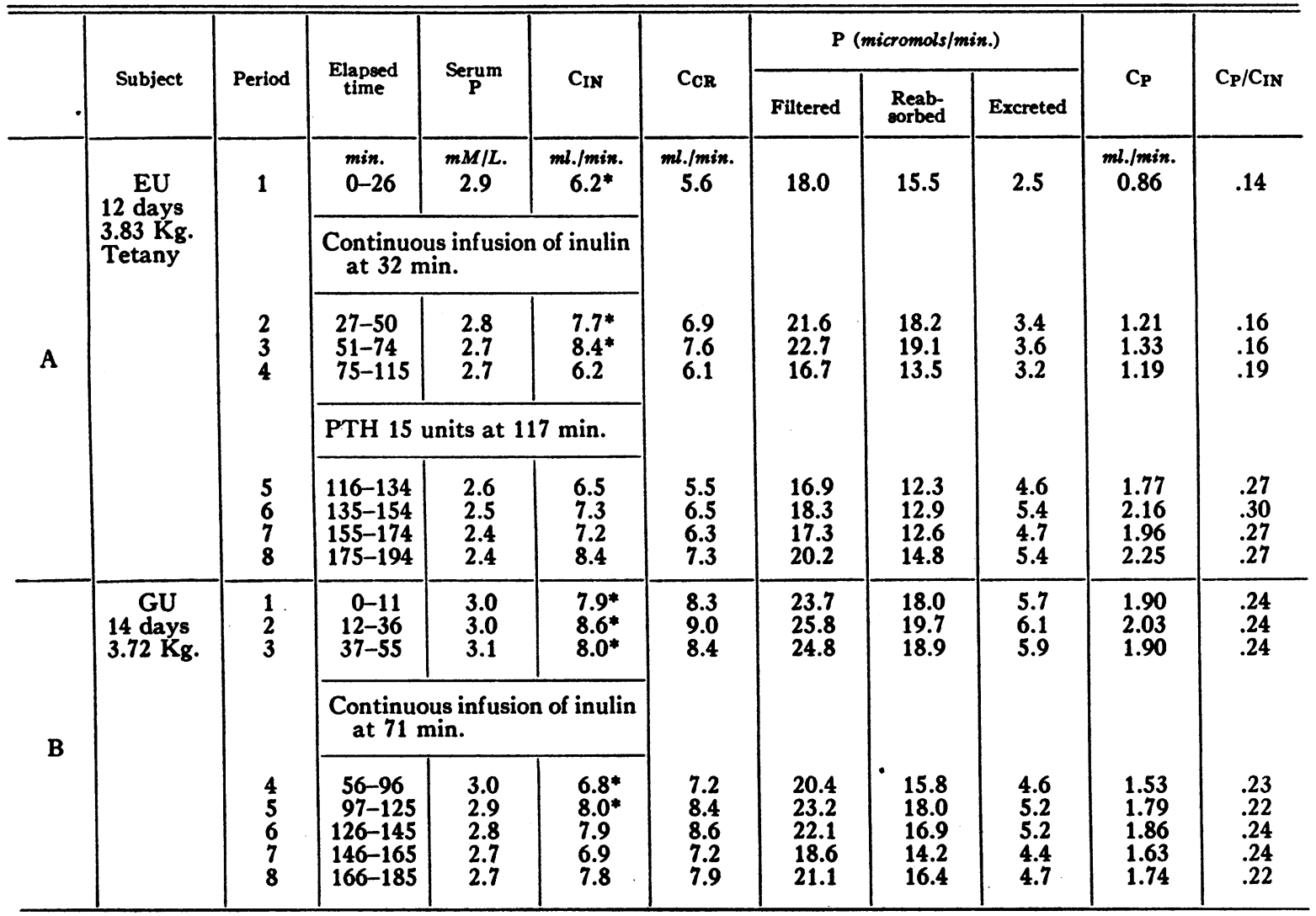

- Values calculated as explained in Table III. 
TABLE VI

Comparison of renal excretion of phosphate at endogenous serum phosphate concentrations in infants, children, and adults

\begin{tabular}{|c|c|c|c|c|c|c|c|c|}
\hline \multirow{2}{*}{ Subjects } & \multirow{2}{*}{ Number } & \multirow{2}{*}{ GFR } & \multirow{2}{*}{$\begin{array}{l}\text { Serum } P \\
\text { conc. }\end{array}$} & \multicolumn{3}{|c|}{$\begin{array}{l}\text { Phosphate } \\
\text { (micromols/min./1.73 } \mathbf{M}^{2} \text { ) }\end{array}$} & \multirow{2}{*}{$\underset{\text { Clearance }}{\mathbf{P}}$} & \multirow{2}{*}{$\mathrm{C}_{\mathbf{P}} / \mathbf{C}_{\mathrm{IN}}$} \\
\hline & & & & Filtered & $\begin{array}{l}\text { Reab- } \\
\text { sorbed }\end{array}$ & Excreted & & \\
\hline $\begin{array}{l}\text { Newborn infants (cow's milk) } \\
\text { Newborn infants* (cow's milk) } \\
\text { Newborn infants } \dagger \text { (human milk) } \\
\text { Children* } \\
\text { Adults } \\
\text { Adults } \ddagger \\
\text { Adults } \$\end{array}$ & $\begin{array}{r}5 \\
3 \\
9 \\
6 \\
2 \\
10 \\
4\end{array}$ & $\begin{array}{c}m l . / m i n . I \\
1.73 M^{2} \\
55.5 \\
38.2 \\
\overline{116.6} \\
133.3 \\
113.2 \\
-\end{array}$ & $\begin{array}{l}m M / L \\
2.34 \\
2.55 \\
1.98 \\
1.65 \\
1.15 \\
1.04 \\
1.03\end{array}$ & $\begin{array}{r}129.0 \\
97.4 \\
192.4 \\
153.3 \\
117.7 \\
-\end{array}$ & $\begin{array}{r}111.0 \\
79.2 \\
167.0 \\
144.7 \\
113.3\end{array}$ & $\begin{array}{r}18.0 \\
18.2 \\
6.0 \\
25.4 \\
8.6 \\
4.4 \\
13.3\end{array}$ & $\begin{array}{c}\text { ml./min.l } \\
1.73 \mathrm{M}^{2} \\
7.7 \\
7.1 \\
3.0 \\
15.4 \\
7.5 \\
4.2 \\
12.9\end{array}$ & $\begin{array}{l}.14 \\
.19 \\
.13 \\
.06 \\
.04 \\
-\end{array}$ \\
\hline
\end{tabular}

* Richmond, Kravitz, Segar, and Waisman (7).

$\dagger$ Dean and McCance (6).

\$ Lambert, van Kessel, and Leplat (22).

Ollayos and Winkler (23).

of tubular reabsorption. This effect has been disputed by others $(18,19)$. These data also confirm the unpublished observations of Crawford, Osborne, Talbot and Terry (20) that in newborn infants, an increased rate of renal phosphate excretion occurs in response to exogenous parathyroid extract.

\section{E. Comparison of renal excretion of phosphate in newborn infants and adults}

The finding of Dean and McCance (6) that phosphate clearances are much lower in newborn infants than in adults has been interpreted as evidence of a limitation of the infant's ability to excrete phosphate in comparison with adults. Table VI shows interesting quantitative differences between infants and normal adults in the mechanisms for renal excretion of inorganic phosphate. Surface area appears to provide the best standard of reference for comparing renal functions in subjects of different sizes (21). Mean values for rates of filtration, reabsorption, and excretion of phosphate and phosphate clearances corrected to $1.73 \mathrm{M}^{2}$ observed in the five infants whose endogenous serum phosphate concentrations ranged from 2.1 to $2.5 \mathrm{mM} / \mathrm{L}$. are included in Table VI. These data are chosen for comparison with adult values because the serum phosphate concentrations in these infants represent the normal range for infants receiving cow's milk. Included in Table VI are mean values for ten normal adults reported by Lambert, van Kessel, and Leplat (22) ; for three normal adults and one with mild essential hyper- tension reported by Ollayos and Winkler $(23) ;^{6}$ for six older children and three newborn infants reported by Richmond, Kravitz, Segar and Waisman (7) ; and for nine infants observed by Dean and McCance (6) ; together with two normal adults studied by the present authors.

It is apparent from Table VI that, on the basis of surface area, newborn infants can excrete phosphate at a higher rate than fasting adults even though glomerular filtration rate in the infants is less than one-half that of adults. In the infants reported here higher rates of excretion are due to higher serum phosphate concentrations and lower rates of tubular reabsorption of phosphate. Phos-

- Ollayos and Winkler (23) have demonstrated a marked diurnal variation in rate of phosphate excretion. Although it is not known whether infants show similar fluctuations, for purposes of comparison the values taken from Ollayos and Winkler represent their control periods ( 1 to 4 ) extending from 65 to 360 minutes after the observations were begun (about 7:00 a.m.). This range of time covers the period during which observations on infants and adults were made in the present study.

It is not possible to compare the values given in Table VI with those on adults reported by Dean and McCance (6). They confirmed the finding of diurnal variations in adults but did not give values for individual periods for most of their adult subjects. In their subjects Nos. 14 and 15, for whom forenoon values were given, the phosphate clearances were 6.5 and $6.6 \mathrm{ml} . / \mathrm{min}$., respectively, which are in the same range as those of Richmond, Kravitz, Segar, and Waisman (7), Lambert, van Kessel, and Leplat (22), and Ollayos and Winkler (23), and those reported here. 
phate clearances, however, are in the same broad range.

These quantitative differences in renal excretion of inorganic phosphate between newborn infants receiving cow's milk and fasting adults should not be interpreted as indicating differences in renal function per se. Gardner and his associates (4) have demonstrated that phosphate excretion and consequently phosphate clearances vary markedly with phosphate intake. It is apparent from the data of Dean and McCance (6) (Table VI) obtained from infants receiving human milk (4) that under other circumstances newborn infants may not be excreting phosphate at rates as high as adults.

\section{DISCUSSION}

Renal retention of phosphate implies either abnormally decreased filtration or increased tubular reabsorption of phosphate or a combination of both.

The occurrence of elevated serum phosphate concentrations in young infants receiving cow's milk of high phosphate content has been attributed to a limitation in renal excretion of phosphate due either to renal immaturity per se or insufficient parathyroid activity or a combination of both. In a group of infants on similar intakes of phosphate we have observed no apparent relationship between rate of phosphate excretion and serum phosphate concentrations.

Infants with widely varying serum phosphate concentrations were found to be filtering, reabsorbing, and excreting phosphate at rates which were in general comparable. Insofar as the rate of phosphate reabsorption is a measure of parathyroid activity, these data indicate that differences in endogenous parathyroid activity do not account for differences in serum phosphate concentrations in these infants. On the other hand, a relationship does seem to exist between elevation of serum phosphate and lower rates of glomerular filtration. It would appear, therefore, that infants receiving high intakes of phosphate, who have low rates of glomerular filtration, excrete the required amount of phosphate by elevation of serum phosphate concentration rather than by further lowering of the rate of tubular reabsorption, which in relation to phosphate filtered is less than that observed in adults.

Why infants with lower rates of glomerular fil- tration do not have lower rates of tubular reabsorption which would permit the same excretion at lower serum phosphate concentration, cannot be answered at present. Conceivably, failure to further reduce the rate of tubular reabsorption could be due, as suggested by Dean and McCance (6), to inherent renal glomerular-tubular imbalance or to either inadequate parathyroid activity or decreased responsiveness to parathyroid hormone. We observed no difference in the response of infants with different serum phosphate concentrations to similar amounts of exogenous parathyroid extract. If this circumstance were to be attributed to altered parathyroid function, it would appear to represent inadequate compensatory hyperparathyroidism $(24,25)$ rather than absolute hypoparathyroidism since the fraction of filtered phosphate excreted by infants is higher than that in adults (Table III) and is similar in all infants (Table I).

Intestinal absorption of phosphate directly affects rate of renal excretion of phosphate as demonstrated by observations made in a single infant before and after a five-day period of reduced intestinal absorption of phosphate. After aluminum hydroxide gel, phosphate practically disappeared from the urine although there was no change in endogenous serum phosphate concentration ${ }^{5}$ or glomerular filtration rate. Similarly, the small quantities of phosphate in urines of infants on breast milk may be considered a consequence of the low dietary phosphate intake and high metabolic demand. It is only under such circumstances that a low renal excretion of phosphate would, by reducing the rate of excretion of buffer base (26), influence the susceptibility of young infants to acidosis. Perhaps of greater interest is the fact that the "ability" of a single infant to excrete a large load of ingested phosphate was markedly decreased due wholly to increased tubular reabsorption following a period of low intake of phosphate. The "ability" of an infant to excrete phosphate is thus markedly influenced by dietary intake of phosphate as well as by the degree of "maturity" of renal function.

It is difficult to attempt to compare infants with adults in respect to their "ability" to excrete phosphate. Under the conditions of the present observations and with values corrected on the basis of surface area, these infants receiving cow's milk 
excreted phosphate at higher rates than adults and had values for phosphate clearances in the same range. This observation is in disagreement with the conclusions of Dean and McCance (6). However, their observations were made on infants receiving breast milk. "Average values" for clearances of electrolytes cannot be interpreted in the same sense as clearances representing discrete kidney functions. Differences in intake, retention, hormonal status, metabolic demand and perhaps other factors complicate the problem so that comparisons of "average values" for electrolyte clearances in infants and adults have limited significance.

\section{SUMMARY AND CONCLUSIONS}

The concentration in serum and the rate of urinary excretion of inorganic phosphate were measured simultaneously with estimations of glomerular filtration rate in 17 infants and in two adults. The newborn infants included two groups defined by the presence of a normal or elevated endogenous serum phosphate concentration. Seven of the infants in the latter group had neonatal tetany.

Observations were made under one or more of the following conditions: 1) at endogenous concentrations of serum phosphate ; 2 ) at elevated concentrations of serum phosphate resulting from oral ingestion of phosphate ; 3 ) before and after a period of decreased intestinal absorption of phosphates achieved by ingestion of aluminum hydroxide gel; and 4) before and after the intravenous administration of parathyroid extract.

The observations are interpreted as indicating that: 1) differences in serum phosphate concentrations in normal infants on similar diets may reflect differences in rates of glomerular filtration but cannot be related to differences in rates of renal excretion or tubular reabsorption of phosphate; 2) insofar as the rate of phosphate reabsorption is a measure of parathyroid activity, differences in endogenous parathyroid activity do not account for differences in serum phosphate concentrations in these infants ; 3) a maximal rate of tubular reabsorption of phosphate can be demonstrated in young infants, and infants on cow's milk are reabsorbing phosphate at this maximal rate ; 4) changes in this maximal rate of tubular reabsorption of phosphate may be evoked by changes in intestinal absorption of phosphate; 5 ) the renal response of young infants to parathyroid extract given intravenously is similar to that of adults; and 6) although infants receiving cow's milk can excrete phosphate at a higher rate per unit surface area than fasting adults, so many non-renal factors influence the rate of renal phosphate excretion that comparisons between infants and adults do not afford a measure of their comparative renal "ability" to excrete phosphate.

\section{ACKNOWLEDGMENTS}

We are indebted to Flora Hurwitz, R. N., for nursing and technical assistance.

\section{REFERENCES}

1. Pitts, R. F., and Alexander, R. S., The renal reabsorptive mechanism for inorganic phosphate in normal and acidotic dogs. Am. J. Physiol., 1944, $142,648$.

2. Ayer, J. L., Schiess, W. A., and Pitts, R. F., Independence of phosphate reabsorption and glomerular filtration in the dog. Am. J. Physiol., 1947, 151, 168.

3. Pitts, R. F., Lotspeich, W. D., Schiess, W. A., and Ayer, J. L., The renal regulation of acid-base balance in man. I. The nature of the mechanism for acidifying the urine. J. Clin. Invest., 1948, 27, 48.

4. Gardner, L. I., MacLachlan, E. A., Pick, W., Terry, M. L., and Butler, A. M., Etiologic factors in tetany of newly born infants. Pediatrics, 1950, 5, 228.

5. McCance, R. A., and von Finck, M. A., The titratable acidity, $\mathrm{pH}$, ammonia and phosphates in the urines of very young infants. Arch. Dis. Child., 1947, 22, 200.

6. Dean, R. F. A., and McCance, R. A., Phosphate clearances in infants and adults. J. Physiol., 1948, 107, 182.

7. Richmond, J. B., Kravitz, H., Segar, W., and Waisman, H. A., Renal clearance of endogenous phosphate in infants and children. Proc. Soc. Exper. Biol. \& Med., 1951, 77, 83.

8. Bakwin, H., Pathogenesis of tetany of the newborn. Am. J. Dis. Child., 1937, 54, 1211.

9. Bakwin, H., Tetany in newborn infants; relation to physiologic hypoparathyroidism.. J. Pediat., 1939, $14,1$.

10. McCance, R. A., Renal physiology in infancy. Am. J. Med., 1950, 9, 229.

11. Clark, E. P., and Collip, J. B., A study of the Tisdall method for the determination of blood serum calcium with a suggested modification. J. Biol. Chem., 1925, 63, 461. 
12. Fiske, C. H., and SubbaRow, Y., Colorimetric determination of phosphorus. J. Biol. Chem., 1925, 66, 375.

13. Barnett, H. L., Hare, K., McNamara, H., and Hare, R., Measurement of glomerular filtration rate in premature infants. J. Clin. Invest., 1948, 27, 691.

14. Harrison, H. 'E., and Harrison, H. C., Renal excretion of inorganic phosphate in relation to action of vitamin $\mathrm{D}$ and parathyroid hormone. J. Clin. Invest., 1941, 20, 47.

15. Freeman, S., and Freeman, W. M. C., Phosphorus retention in children with chronic renal insufficiency. The effect of diet and of the ingestion of aluminum hydroxide. Am. J. Dis. Child., 1941, 61, 981.

16. Shorr, E., and Carter, A. C., Aluminum gels in the management of renal phosphatic calculi. J. A. M. A., 1950, 144, 1549.

17. Michie, A. J., and Shorey, J. M., Parathyroid extract hyperphosphaturia in hypoparathyroidism. Federation Proc., 1950, 9, 88.

18. Jahan, I., and Pitts, R. F., Effect of parathyroid on renal tubular reabsorption of phosphate and calcium. Am. J. Physiol., 1948, 155, 42.
19. Hogben, C. A. M., and Bollman, J. L., Renal reabsorption of phosphate: normal and thyroparathyroidectomized dog. Am. J. Physiol., 1951, 164, 670.

20. Crawford, J. D., Osborne, M. M., Jr., Talbot, N. B., and Terry, M. L., Parathyroid glands and phosphorus homeostasis. Cited in reference 4 above.

21. Rubin, M. I., Bruck, E., and Rapoport, M., Maturation of renal function in childhood: clearance studies. J. Clin. Invest., 1949, 28, 1144.

22. Lambert, P. P., van Kessel, E., and Leplat, C., Etude sur l'élimination des phosphates inorganiques chez l'homme. Acta. med. Scandinav., 1947, 128, 386.

23. Ollayos, R. W., and Winkler, A. W., Urinary excretion and serum concentration of inorganic phosphate in man. J. Clin. Invest., 1943, 22, 147.

24. Kaplan, E., Parathyroid gland in infancy. Arch. Path., 1942, 34, 1042.

25. Albright, F., and Reifenstein, E. C., Jr., The Parathyroid Glands and Metabolic Bone Disease. Williams \& Wilkins Co., Baltimore, 1948.

26. Pitts, R. F., Acid-base regulation by the kidney. Am. J. Med., 1950, 9, 356. 